\title{
Use of plant growth regulators in the conservation of grapes "Italy" as aids in post-harvest
}

\author{
Fabiane Correa de Almeida, Jessicka Fernanda Lopes de Camargo Cham, Bruna Lais Ham, Sabrine Maria Ferreira, \\ Marcos Gabbardo, and Juan Saavedra del Aguila ${ }^{a}$ \\ Federal University of Pampa (UNIPAMPA) course - Bachelor of Oenology - Campus Dom Pedrito \\ Address: Twenty-One \# 80 April, Dom Pedrito, Rio Grande do Sul (RS) CEP 96450-000, Brazil
}

\begin{abstract}
The objective of this study was to evaluate the effect of plant growth regulators on postharvest fine table grapes "Italy". The grapes were harvested at a commercial vineyard in the city of Canguçu, RS, Brazil and transported to the UNIPAMPA-Campus Dom Pedrito. The treatments were: distilled water (control); $500 \mathrm{ppb}$ of 1-methylcyclopropene [MCP-1 $\left(12 \mathrm{~h}\right.$ at $\left.20^{\circ} \mathrm{C}\right)$ ]; $10 \mu \mathrm{M}$ of salicylic acid and; $100 \mathrm{ppm}$ of ethylene. The design was randomized, where each treatment had three replicates, and each replicate consisted of 3 bunches (about $2 \mathrm{~kg}$ ). The evaluations were performed on the day of harvest (characterization - day zero) and at 7 and 14 days of storage at $18^{\circ} \mathrm{C}$ controlled. It was evaluated: browning of stems, loss of fresh bunch weight, percentage of abscission of berries, rot incidence, total soluble solids - SS ( ${ }^{\circ}$ Brix), percentage of dehydration of the stem, titratable acidity - AT (\% tartaric acid), gluconic acid, "ratio" (SS/TA) and density. It was found that the application of $10 \mathrm{mM}$ of salicylic acid in postharvest fine table grapes "Italy" can help a smaller abscission of berries and less dehydration of the stem, which may prolong the shelf life of these grapes.
\end{abstract}

\section{Introduction}

The main problems of table grapes after harvest and during storage are dehydration, berry drops and rots, which can be minimized by proper and careful handling of the fruit [1]. The widest possible knowledge of the changes that occur in berries from growth to senescence, especially since the maturity, and the factors that influence them is essential to the quality requirements by different types of consumers. In this case, the monitoring and control of storage conditions and inputs used in post-harvest practices amplify the competitive potential and preserve the sensory properties of grape [2]. Ethylene is a plant hormone produced naturally by plants and affects the longevity of the same, through the induction of physiological responses [3], its main effect on the horticultural products is the induction of increased respiratory activity, which increases the metabolic activity and anticipates senescence [4]. Treatment with inhibitors delays the injurious effects of ethylene [5,6]. The compound 1-methylcyclopropene (1MCP), has been used in post-harvest treatments, because it is a nontoxic compound and efficient inhibitor of ethylene. The MCP-1 binds in an irreversibly way to the receptor sites of cell membranes, preventing the physiological stimulus of ethylene [4]. Another regulator used as an ethylene inhibitor is salicylic acid (SA) due mainly to be related to the reduction of the ACC oxidase activity, ethylene forming enzyme [7]. This plant growth regulator plays an important role in regulating

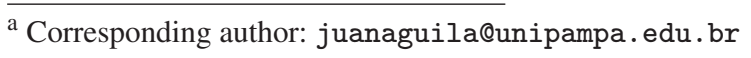

physiological processes, plants resistant to biotic and abiotic stresses [8-10]. SA reduces the concentration of free radicals and reduces the activity of enzymes such as phenylamine ammonia-lyase (PAL) and peroxidase (POD), both enzymes are linked to lignification of tissues process [11]. Therefore, the objective of this study was to evaluate the effect of different plant growth regulators on postharvest conservation of the grape "Italy" stored at $18^{\circ} \mathrm{C}$.

\section{Materials e methods}

The experiment was conducted by the Center for Study, Research and Extention in Oenology $\left(\mathrm{NEPE}^{2}\right)$ of UNIPAMPA - Campus Dom Pedrito, RS, Brazil. The grapes were harvested at a commercial vineyard in the city of Canguçu, RS, and carefully transported to the UNIPAMPA. In the laboratory, the bunches which had good health were selected.

The design was randomized, each treatment had 3 replicates and each replicate consisted of three bunches of approximately $2 \mathrm{~kg}$. The treatments were: (T1) distilled water (control); (T2)500 pbb of 1-methylcyclopropene [1$\operatorname{MCP}\left(12 \mathrm{~h}\right.$ at $20^{\circ} \mathrm{C}$; (T3) $10 \mu \mathrm{M}$ of salicylic acid and; [T4] $100 \mathrm{ppm}$ of ethylene. Treatment with distilled water (S1); salicylic Acid (T3) and; ethylene (T4), were applied with manual spray to point of runoff.

The grapes treated with 1-methylcyclopropene (T2), were packed in sealed plastic box, during the twelve hours at a temperature of $20^{\circ} \mathrm{C}$. The evaluations were performed on the day of harvest (characterization - day zero) and at 


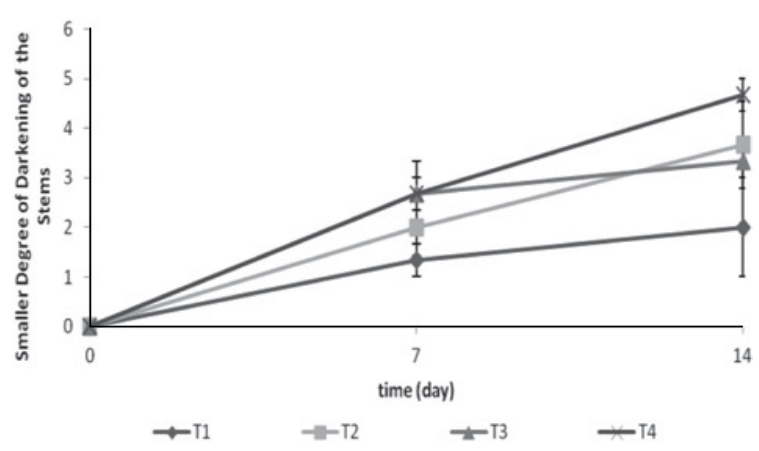

Figure 1. Darkening of the stem bunch of vine "Italy" treated or not with plant growth regulators. $\mathrm{T} 1=$ distilled water (control); $\mathrm{T} 2=500 \mathrm{pbb}$ of 1 -methylcyclopropene $\left[1-\mathrm{MCP}\left(12 \mathrm{~h}\right.\right.$ at $\left.20^{\circ} \mathrm{C}\right]$; $\mathrm{T} 3=10 \mu \mathrm{M}$ of salicylic acid and; T4 $=100 \mathrm{ppm}$ of ethylene. Vertical bars represent the standard error of the mean $(n=3)$.

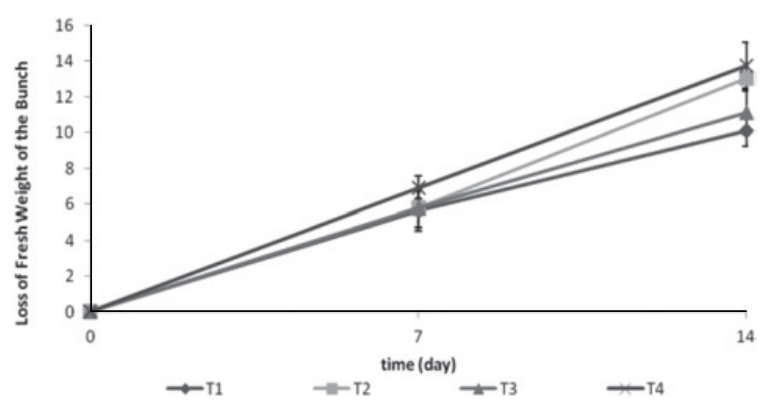

Figure 2. Loss of the fresh weight bunch of the vine "Italy" treated or not with plant growth regulators. T1 $=$ distilled water (control); $\mathrm{T} 2=500 \mathrm{pbb}$ of 1 -methylcyclopropene $[1-\mathrm{MCP}(12 \mathrm{~h}$ at $20^{\circ} \mathrm{C}$; $\mathrm{T} 3=10 \mu \mathrm{M}$ of salicylic acid and; $\mathrm{T} 4=100 \mathrm{ppm}$ of ethylene. Vertical bars represent the standard error of the mean $(\mathrm{n}=3)$.

7 and 14 days of controlled storage at $18^{\circ} \mathrm{C}$ as an attempt to simulate the conditions of commercialization of grapes in a supermarket.

The grapes were evaluated for browning index of stem, using the scale: 1 - to green, fresh and turgid stems; 2 - green, opaque; 3 - green to brown; 4 - predominantly brown; 5 - brown pardo and dry. Fresh weight loss, expressed in grams, with performed weighing of the repetitions on the first day of the experiment and after seven and fourteen days. Abscission of berries percentage was determined by the mass difference obtained by weighting of the bunches and dropped berries. Rot incidence, expresses in \%, was used a scale were: $0=0 \% ; 1<5 \% ; 2=5-25 \% ; 3=25-$ $50 \% ; 4=>50 \%$. Total Soluble Solids - SS ( ${ }^{\circ}$ Brix) was determined with a digital refractometer. Percentage of dehydration of stem, determined by weighing the fresh stems and weighing after being removed from the stove at $72{ }^{\circ} \mathrm{C}$ for three days (constant weight), calculating the difference between values. Titratable Acidity - TA (\% tartaric acid) was determined by titration with $0.1 \mathrm{~N} \mathrm{NaOH}$ to $\mathrm{pH} 8.1$ and the results expressed in $\%$ of tartaric acid. Gluconic acid, physical-chemical analysis by infrared spectrometry technique by Fourier transform (FTIR) indicates the concentration of rot in the wort.

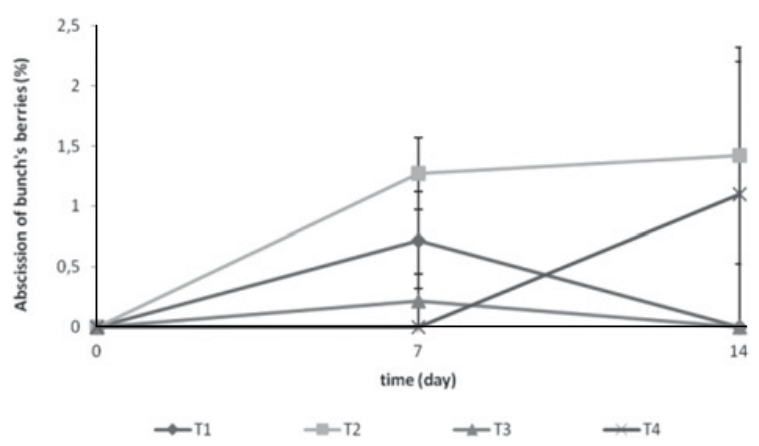

Figure 3. (\%) Abscission of bunch's berries of vine "Italy" treated or not with plant growth regulators. $\mathrm{T} 1=$ distilled water (control); $\mathrm{T} 2=500 \mathrm{pbb}$ of 1 -methylcyclopropene $[1-\mathrm{MCP}(12 \mathrm{~h}$ at $20^{\circ} \mathrm{C}$ ]; $\mathrm{T} 3=10 \mu \mathrm{M}$ of salicylic acid and; T4 $=100 \mathrm{ppm}$ of ethylene. Vertical bars represent the standard error of the mean $(\mathrm{n}=3)$.
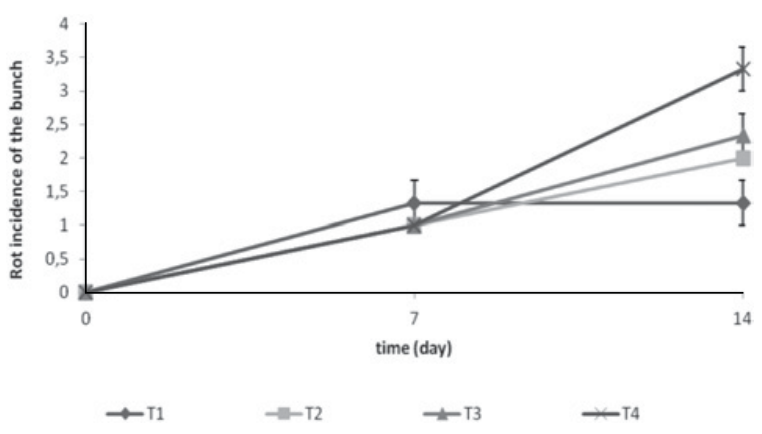

Figure 4. Rot incidence of the bunch of vine "Italy" treated or not with plant growth regulators. $\mathrm{T} 1=$ distilled water (control); $\mathrm{T} 2=500 \mathrm{pbb}$ of 1 -methylcyclopropene $\left[1-\mathrm{MCP}\left(12 \mathrm{~h}\right.\right.$ at $\left.20^{\circ} \mathrm{C}\right]$; $\mathrm{T} 3=10 \mu \mathrm{M}$ of salicylic acid and; T4 $=100 \mathrm{ppm}$ of ethylene. Vertical bars represent the standard error of the mean $(n=3)$.

"Ratio" (SS/TA), determined by the differential between soluble solids and titratable acidity. Density, physicalchemical analysis by the infrared spectrometry technique by Fourier transform (FTIR).

The results obtained were subjected to analysis of variance ( $\mathrm{F}$ test) and multiple comparison of means by Tukey test at $5 \%$ of probability.

\section{Results e discussion}

A smaller degree of darkening of the stems was observed in the control treatment (T1), and higher in T3 and T4 (Fig. 1). The dimming feature and rachis drying, accompanied by the softening of the berries, were indicated as the main symptoms of dehydration grapes [14]. As for the loss of fresh weight of the bunch, the T1 during the 14 days of experimentation showed the smallest loss; on the other side, T2 and T4 had significant losses at the end of the experiment (Fig. 2). However, in an experiment conducted with grape "Isabel", found no additional effect of fresh weight loss after application of 1-MCP [15].

The abscission of the berries was lower in the grapes with the application of $10 \mathrm{uM}$ of salicylic acid (T3) (Fig. 3). The abscission of the berries is associated with 


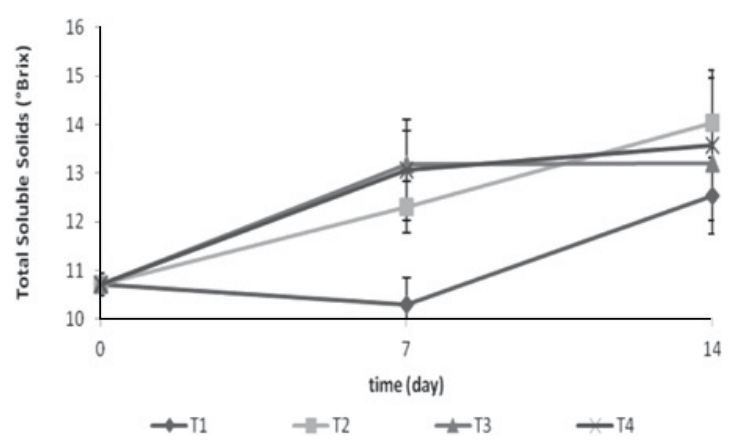

Figure 5. Total Soluble Solids ( ${ }^{\circ}$ Brix) of the bunch of vine "Italy" treated or not with plant growth regulators. T1 $=$ distilled water (control); T2 $=500 \mathrm{pbb}$ of 1-methylcyclopropene [1$\operatorname{MCP}\left(12 \mathrm{~h}\right.$ at $\left.20^{\circ} \mathrm{C}\right] ; \mathrm{T} 3=10 \mu \mathrm{M}$ of salicylic acid and; $\mathrm{T} 4=$ $100 \mathrm{ppm}$ of ethylene. Vertical bars represent the standard error of the mean $(n=3)$.

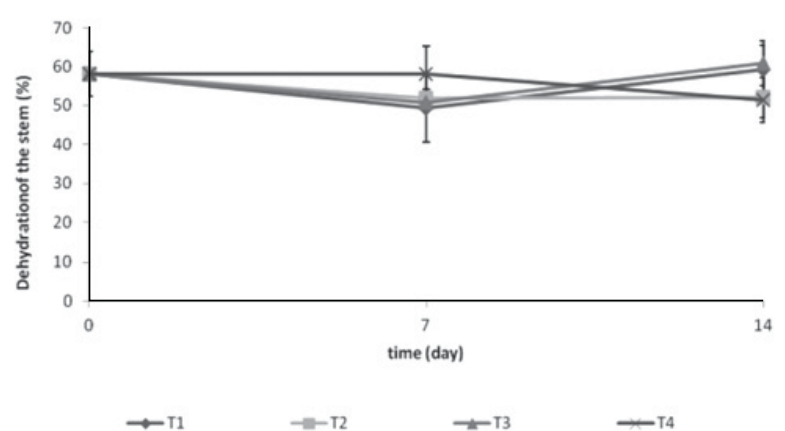

Figure 6. Dehydration of the stem from the bunch of the vine "Italy" treated or not with plant growth regulators (\%). T1 = distilled water (control); T2 $=500 \mathrm{pbb}$ of 1-methylcyclopropene $\left[1-\mathrm{MCP}\left(12 \mathrm{~h}\right.\right.$ at $\left.20^{\circ} \mathrm{C}\right] ; \mathrm{T} 3=10 \mu \mathrm{M}$ of salicylic acid and; $\mathrm{T} 4=$ $100 \mathrm{ppm}$ of ethylene. Vertical bars represent the standard error of the mean $(n=3)$.

the increase of the activity of hidrolases of cellulase and polygalacturonase enzymes [12].

The rot incidence in grapes was lower treatment control (T1), however, treatment with ethylene (T4) showed the highest rot incidence (Fig. 4). This result can be explained because of the action of ethylene in triggering various physiological and biochemical processes related to maturation, increasing the respiratory rate of the same.

The SS had an increase during storage, without significant differences between treatments, this increase in SS is probably due to the concentration of soluble solids by water loss (Fig. 5). Non-climacteric fruits, such as grapes, hardly changes in sugar content during post-harvest [13]. However, there may be a significant increase in the initial sugar content due to degradation of the cell wall [4].

The percentage of stems dehydration was lower in the control treatment (T1) and in the treatment with the application of $10 \mu \mathrm{M}$ of salicylic acid (T3) (Fig. 6). Other studies confirm the positive action of SA in maintaining of the postharvest quality of roses "Vega", helping the water balance of the rods [16].

The TA decreased in all treatments, with no significant differences between these throughout the experiment (Fig. 7). However, grapes from the cultivar "Isabel" evaluated after the use of $1-\mathrm{MCP}$ showed a

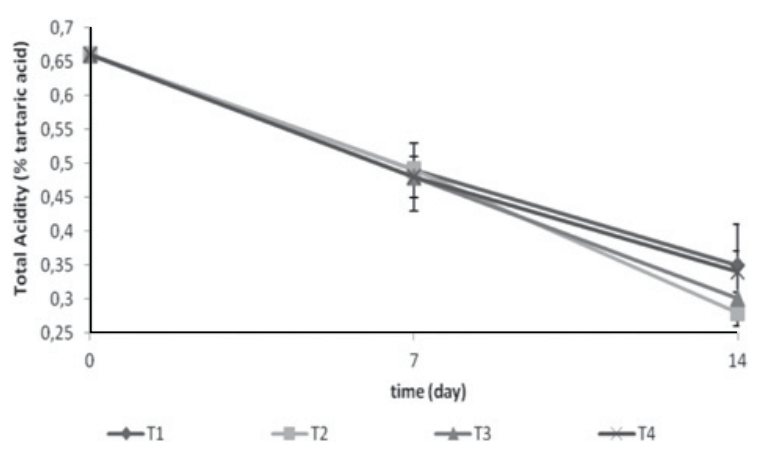

Figure 7. Total Acidity (\% tartaric acid) of the bunch from the vine "Italy" treated or not with plant growth regulators (\%). T1 = distilled water (control); T2 $=500 \mathrm{pbb}$ of 1-methylcyclopropene [1-MCP $\left(12\right.$ hat $\left.20^{\circ} \mathrm{C}\right] ; \mathrm{T} 3=10 \mu \mathrm{M}$ of salicylic acid and; $\mathrm{T} 4=$ $100 \mathrm{ppm}$ of ethylene. Vertical bars represent the standard error of the mean $(\mathrm{n}=3)$.

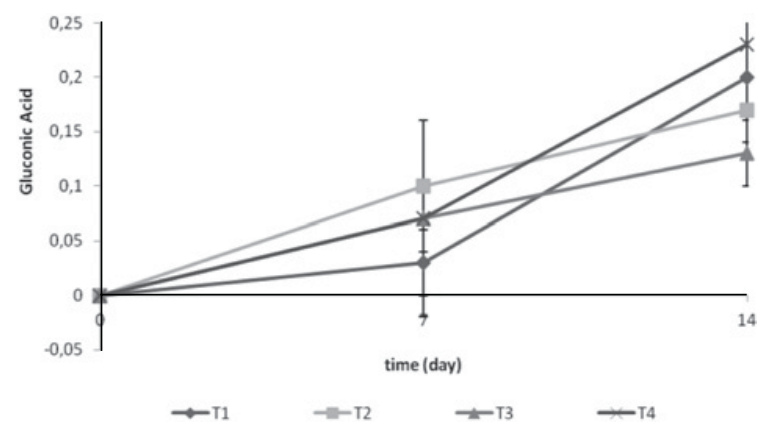

Figure 8. Gluconic acid of the bunch from the vine "Italy" treated or not with plant growth regulators $(\%) . \mathrm{T} 1=$ distilled water (control); T2 $=500 \mathrm{pbb}$ of 1-methylcyclopropene [1-MCP $(12 \mathrm{~h}$ at $20^{\circ} \mathrm{C}$ ], T3 $=10 \mu \mathrm{M}$ of salicylic acid and;. T4 $=100 \mathrm{ppm}$ of ethylene. Vertical bars represent the standard error of the mean $(\mathrm{n}=3)$.

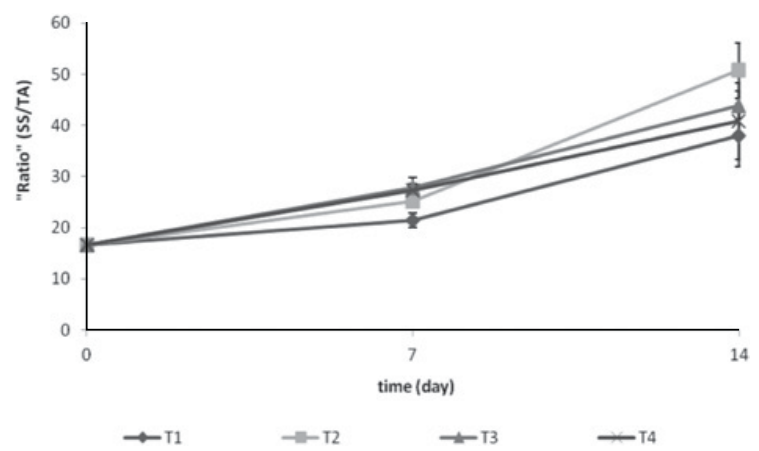

Figure 9. "Ratio" of the bunch from the vine "Italy" treated or not with plant growth regulators $(\%) . \mathrm{T} 1=$ distilled water (control); $\mathrm{T} 2=500 \mathrm{pbb}$ of 1 -methylcyclopropene $\left[1-\mathrm{MCP}\left(12 \mathrm{~h}\right.\right.$ at $\left.20^{\circ} \mathrm{C}\right]$; $\mathrm{T} 3=10 \mu \mathrm{M}$ of salicylic acid and; $\mathrm{T} 4=100 \mathrm{ppm}$ of ethylene. Vertical bars represent the standard error of the mean $(n=3)$.

significant maintenance of titratable acidity during the experiment [15].

The presence of gluconic acid, considered an indicator of grape rot showed up in larger quantities in grapes of the treatments (T1) and (T4), confirming the results previously reported by variable of rot incidence (Fig. 8).

The relation between sugar and acidity known as "ratio", was higher in grapes (T2), but all treatments showed an increase over the 14 days of experiment 


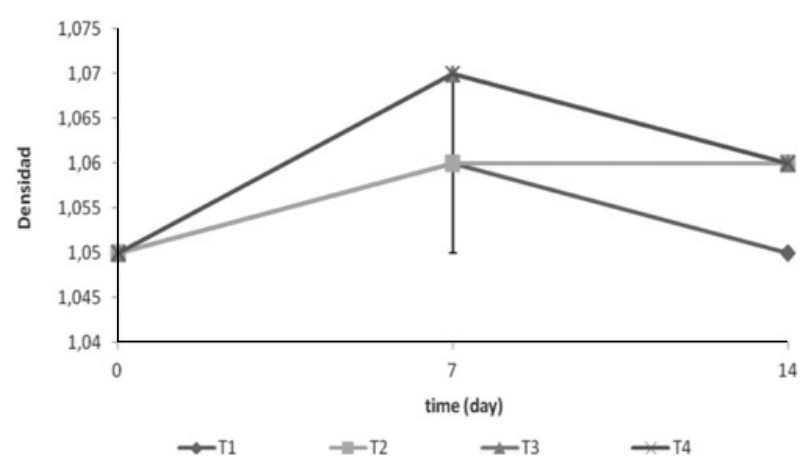

Figure 10. Density of the bunch from the vine "Italy" treated or not with plant growth regulators $(\%)$. T1 $=$ distilled water (control); T2 $=500 \mathrm{pbb}$ of 1 -methylcyclopropene $[1-\mathrm{MCP}(12 \mathrm{~h}$ at $20^{\circ} \mathrm{C}$ ], T3 $=10 \mu \mathrm{M}$ of salicylic acid and;. T4 $=100 \mathrm{ppm}$ of ethylene. Vertical bars represent the standard error of the mean $(\mathrm{n}=3)$.

(Fig. 9). Result differs from the work done through the use of cultivar "Isabel", where the 1-MCP did not affect the relation between sugar and acidity [15].

The density had a significant increase in treatment T4 to the 7th day. However, there was a reduction in the density of all treatments until the end of the experiment (day 14) (Fig. 10). The density is directly related to $\mathrm{SS}\left({ }^{\circ}\right.$ Brix), due to the presence of glucose and fructose, considered its main components.

\section{Conclusion}

It is concluded that the application of $10 \mu \mathrm{M}$ of salicylic acid in the post-harvest of table grapes "Italy", can help a smaller abscission of berries and lower dehydration of the stem, which may prolong the shelf life of these grapes.

\section{References}

[1] R. Kluge, J. Nachtigal, J. Fachinello, A. Bihalva. Fisiologia e manejo pós-colheita de frutas de clima temperado. 2. ed. rev. e ampl. Livraria e Editora Rural, (2002)

[2] M. Lima. Fisiologia, Tecnologia e Manejo PósColheita. In: José Monteiro Soares; Patrícia Coelho de Souza Leão. (Org.). A Vitivinicultura no Semiárido Brasileiro. 1 ed. Brasília: Embrapa Informática Agropecuária/Embrapa Semi-Árido, 1, p. 597-656, (2009)

[3] F. Finger, M. Campanha, J. Barbosa, P. Fontes. Influence of ethephon, silver thiosulfate and sucrose pulsing on bird of paradise vase life. Revista Brasileira de Fisiologia Vegetal, Campinas, 11, n.2, p.119-122, (1999)

[4] M. Chitarra, A. Chitarra. Pós-colheita de frutos e hortaliças: fisiología e manuseio. 2. ed. rev. e ampl. Lavras: UFLA, (2005)
[5] J. Van Standen. The effect of emasculation on the endogenous cytokinin levels of Cymbidium flowers. Scientia Horticulture, Amsterdam, 10, n.3, p. 277284, (1979)

[6] E. Woltering, H. Harkema. Verkleuring van Cymbidium-bloemen. Vakblad voor de Bloemisterij, 41, p. 52-53, (1983)

[7] P. Jun, N. Nishimura, Y. Kubo. Biosynthesis of traceethylene in some fruits. Journal of the Japanese Society for Horticultural Science, 61, n.1, p. 199204, (1999)

[8] Y. He, Y. Liu, W. Cao, M. Hua, B. Xu, B. Huang. Effects of salicylic acido $n$ heat tolerance associated with antioxidant metabolism in Kentucky blue grass. Crop Science, 45, p. 988-955, (2005)

[9] B. Mauchi-Mani, J. Métraux. Salicylic acid and systemic acquired resistence to pathologen attack. Annals of Botany, 82, p. 535-540, (1998)

[10] A. Molina, P. Bueno, M. Marín, M. RodríguezRosales, A. Belver, K. Venema, J. Donaire. Involvement of endogenous salicylic acid content, lipoxygenase and antioxidante enzyme activities in the response of tomato cell suspension cultures to $\mathrm{NaCl}$. New Phytologist, 156, p. 409-415, (2002)

[11] C. Cai, C. Xu, X. Li, I. Ferguson, K.Chen. Accumulation of lignin in relation to chang in activies of lignification enzimes in loquat fruit flesh after harvest. Postharvest Biology and Technology, Amsterdam, 40, p. 163-169, Mar, (2006)

[12] Y. Deng, Y. Wu, Y. Li, M. Yang, C. Shi, C. Zheng. A mathematical model for predicting grape berry drop during storage. Postharvest Biology and Technology, Amsterdam, 43, p. 95-101, (2007)

[13] M. Tecchio, M. Terra, P. Cia, E. Paioli-Pires, M. Moura, J. Sanches, E. Benato, J. Hernandes, S. Valentini, J. Sigrist. Efeito do ácido naftalenoácetico $e$ do cloreto de cálico na redução das perdas póscolheita de uva 'Niágara Rosada'. Revista Brasileira de Fruticultura, Jaboticabal, 31, n.1, p. 5361, (2009)

[14] S. Censi, M. Chitarra. Controle da abscisão poscolheita de uva 'Niágara Rosada' Vitis (labrusca L. X vinífera L.): mecanismos decorrentes da aplicação de ANA e cálcio no campo. Revista Brasileira de Fruticultura, Cruz das Almas, 16, n.1, p.146-155, (1994)

[15] R. Silva. Controle de degrane e conservação poscolheita sob $\mathrm{CaCl}_{2}$ e 1-MCP de uva 'Isabel'produzida no Vale do Sirijí (PE/PB). Dissertação (Mestrado em Ciência e Tecnologia de Alimentos) - Universidade Federal da Paraíba, (2010)

[16] G. Geerdink. Efeitos de tratamento pré e póscolheita na qualidade de rosas de corte. (Dissertação Mestrado em Ciências - Fitotecnia) - Escola Superior de Agricultura Luís de Queiroz - Universidade de São Paulo, Piracicaba, (2012) 